\title{
Marketing Approach of Brazilian Wind Energy Sector
}

\author{
Gustavo Henrique Silva de Souza', Nilton Cesar Lima², Jamerson Viegas Queiroz ${ }^{3}$, \\ Antonio Sergio Torres Penedo ${ }^{4}$, Jorge Artur Peçanha de Miranda Coelho', Antonio Carlos Silva Costa'
}

\begin{abstract}
Prospects for the wind energy market have proposed changes of focus to managerial issues. The objective of this article is to map the specific market factors from Brazilian wind energy industry, in order to develop reflections and considerations on the subject, towards to the managerial, strategic and commercial development of the sector. Through an exploratory methodology in empirical format, and by a SWOT analysis of Telescopic Observations Strategic Framework, were found results that show funding and grants determined by Brazilian government, as the big question of the wind energy industry marketing, allowing the economic viability of wind energy projects. Further, it appears that the wind energy industry is eager to investments and has great potential for new business, but there are problems within the producing companies which that have to be assessed, such as the competitiveness capability, the high equipment costs, the installation locations limitations and lack of specialized employees with specific skills and capacities.
\end{abstract}

Keywords: wind energy; energetic management; swot analysis; telescopic observations strategic framework.

\footnotetext{
'University of Alagoas (Universidade Federal de Alagoas). E-mail: souza.g.h.s@hotmail.com.br ${ }^{2}$ University of Uberlândia (Universidade Federal de Uberlândia). Department of Accounting. ${ }^{3}$ Federal University of Rio Grande do Norte (Universidade Federal do Rio Grande do Norte). Department of Master in Production Engineering. Brazil.

${ }^{4}$ University of Uberlândia (Universidade Federal de Uberlândia). Department of Production Engineering.

'University of Alagoas (Universidade Federal de Alagoas). Department of Administration.
} 


\section{Introduction}

The managerial paradigm of the wind energy system has been undergoing a structural process of learning marketing. Due to the technological improvements of wind equipment, to the growth of the wind energy industry in the global electric power industry, to the rise of public incentive policies to renewable resources, and to the reduction in initial investment costs; The focus of managerial issues in the wind energy sector went through a strategic format change (Mills, Wiser and Porter, 2012; Ratinen and Lund, 2012). The cost management changed into price management and technology management changed into innovation management.

Berry (2009) explains that the maturation of the wind energy market has expectations for the sector that exceed the limits related to self-sustainability, the reduction of environmental impacts and the reduction of the high capital costs, establishing itself as a reflex of factors, such as scale production and energy supply. Komor (2004) emphasizes that wind energy already has a very advanced technological support compared to its market opportunities. For this author, the wind energy industry needs actions that can set the wind energy competitively in the electricity market.

Although the economic viability analyzes and cost analyzes are still indispensable, according to Nascimento, Mendonça and Cunha (2012), currently in Brazil, the biggest problem of the wind energy industry is composed of storage, supply and commercialization of wind energy. In this regard, it has especially lack of transmission lines from wind farms (where the wind turbines are) to power substations and also, lack of a complementarity structure between wind energy and hydroelectricity (Silva, Rosa and Araújo, 2005; Dutra and Szklo, 2008a; 2008b).

Therefore, the advance into market perspectives for the wind energy cover both, discussions regarding the costs and public policies, as the energy system and energy trading. Thus defined the lines of discussion, the purpose of this article is to map the market factors specific to the Brazilian wind energy industry and its prospects, in order to develop critical thinking and considerations on the subject, towards management, commercial and strategic development of the sector.

\section{Theoretical Review}

\section{Costs and prices in wind energy sector}

The wind energy industry has become one of the sectors with the highest growth potential of exploitation of renewable energy in the world, due to strong public and private investments, especially since the early 2000s (Lewis, 2010; Mills, Wiser and Porter, 2012).

From this growth, the big question raised is assumed by the high cost of wind energy, in view of $75 \%$ of the cost of a wind energy project come from equipment, and the value of average investment in Brazil, including the turbines and the infrastructure, are of $R \$ 4.2$ million per $M W$ installed (Garbe, Mello and Tomaselli, 20II).

Thus, the reason for the attractiveness of investment in the sector, according to Leite, Borges and Falcão (2006), is in the guarantee of the purchase of wind energy produced by countries governments, as Brazil, China, United States among others, which have established policies in wind energy as a choice of energy source, even if it does not offer, currently, a competitive price in front of conventional energy sources.

For Dutra (2007: 7) the wind energy has shown itself mature enough to a more aggressive participation in the environment of electricity generation worldwide. On the other hand, Silva, Rosa and Araújo (2005) point out that the wind energy sector, in terms of economically attractive power source, has not yet reached a stage of maturity sufficient to compete with other kinds of energy sources. The relevance of wind energy, then, is in its environmental and geopolitical appeal, by a cooperation to a more safe and clean energy supply, in order to reduce the risk of crises in the electricity delivery. Thereby, other factors currently are guiding the expansion of the sector, as the public policies which encourage the wind energy production, through grants, loans and tax exemption, as proposed by Dutra and Szklo (2008a).

In a similar line of thought, Gökçek and Genç (2009) state that the advantage of wind energy is precisely in not using fuel, environmental avoided costs and tax exemption. With this, the wind energy merely has investment costs and maintenance (administration).

However, Garbe, Mello and Tomaselli (201I) go even further, showing that another advantage of wind energy is the low cost of production, when withdrawn the cost of investment. In Table I are shown the production costs for different types of power generation. As can be seen, the production cost of wind energy is relatively competitive with conventional energies such as hydroelectric, nuclear, coal and natural gas energy sources. While, in relation to renewable energy, the wind energy is the most attractive. (See next p. Table I)

On the other hand, including investment costs for equipment, considering a wind farms built in Brazil of a total invest- 
ment of R\$ 650 million for an installed capacity of I40MW (Pacific Hydro, 2012), the average cost has an approximate value $R \$ 590.00 / M W h$ (each MW of installed capacity generates Approximately 7,883 MWh). In other words, it has a really high value, which makes the cost of this energy the big problem of sector.

Nevertheless, Brazilian government has promoted policies to lower the high cost of wind energy in Brazil. And among these policies, there is the new format of electricity auction proposed by the federal government, which has been encouraging the haggle over the price of wind energy (Costa and Pierobon, 2008; Garbe, Mello and Tomaselli, 20II), and the public policies created seeking a support for renewable energy production (Dutra and Szklo, 2008a).

These factors prove to be beneficial to organizational sustainability of wind farms (known also as wind parks) because it relates to economic viability of wind energy projects, considering aspects of profitability and balance. It is in this sense, that in marketing scope, the study of the factors of costs and prices starts to give way to the study of energy policies which are specific of the wind energy industry.

\section{Wind energy polices}

Considering socio-environmental process towards to energy sustainability and in pursuit for clean technologies of electric power to reduce emissions of greenhouse effect gases, the governments of several countries began to provide support for renewable energy generation (Lewis and Wiser, 2007; Ratinen and Lund, 2012). That's because, according to Dutra and Szklo (2008a) and Mills, Wiser and Porter (20I2), several barriers associated with the public policies, still needed to be overcome, especially regarding to the insertion of wind energy within the conventional electric power system.

\begin{tabular}{|c|c|}
\hline GENERATOR TYPE & $\begin{array}{c}\text { MEAN COST } \\
\text { (US\$ per MWh) }\end{array}$ \\
\hline Hydro power & $0.20-0.50$ \\
\hline Nuclear power & $0.30-0.40$ \\
\hline Coal power & $0.40-0.50$ \\
\hline Natural Gas & $0.40-0.50$ \\
\hline Wind energy & $0.40-1.00$ \\
\hline Geothermic power & $0.50-0.80$ \\
\hline Biomass & $0.80-1.20$ \\
\hline Fuel Cell of hydrogen & $1.00-1.50$ \\
\hline Solar photovoltaic & $1.50-3.20$ \\
\hline
\end{tabular}

Table I. Comparison between costs of several production types of energy. Source: From Garbe, Mello and Tomaselli (20I I, p. 40).

\begin{tabular}{|c|c|}
\hline Sector & $\begin{array}{c}\text { Jobs (Workers-year/TWh) } \\
\text { (Fuel production + Energy generator) }\end{array}$ \\
\hline Nuclear Power & 75 \\
\hline Natural Gas & 250 \\
\hline Hydro Power & 250 \\
\hline Petroleum (oil) & 260 \\
\hline Petroleum (oil) offshore & 265 \\
\hline Coal power & 370 \\
\hline Firewood & $733-1,067$ \\
\hline Wind energy & $918-2,400$ \\
\hline Ethanol & $3,711-5,392$ \\
\hline Solar photovoltaic & $29,580-107,000$ \\
\hline
\end{tabular}

Table 2. Jobs in several electricity sectors. Source: Dates from Dutra (2007: 7).

ISSN: 07 I8-2724. (http://www.jotmi.org)

Journal of Technology Management \& Innovation @ Universidad Alberto Hurtado, Facultad de Economía y Negocios. 
Dutra and Szklo (2008a; 2008b) and Mills, Wiser and Porter (2012) point out that these barriers are characterized in several points, such as: the investment costs; the lack of scale and scope; the advanced and specific technology; the great competence of the conventional power industry; the information barriers; the lack of resources and small technological availability; the energy density; and, the energy fluctuation.

From the characterization of these barriers in the start of the implementation of wind energy in the electric power system, is which there were the first incentive strategies for the energy policies specific to wind energy, according to Dutra and Szklo (2008a). The authors claim that the wind energy presents other factors that justify such incentives, particularly, those related to social and environmental issues of wind energy. Namely, not only the barriers to the development of the wind energy system encouraged the creation of these policies, but also the benefits to environment, as well as, the improvement of the electric power system and jobs creation.

Regarding the job creation, the wind energy industry proves to be relevant to local and regional development, since that it has a great capacity for employability compared to other energy sectors (Dutra, 2007). As shown in Table 2, the wind energy industry employs more than almost every sector of conventional energy source. (See previous Table 2)

Nascimento, Mendonça and Cunha (2012) highlight still that the social benefits that the exploration of wind activity can bring to Brazil are countless, and still, can contribute to employment generation, promoting a greater social inclusion within the country. Salles (2004) corroborates this line of thought, arguing that the wind farms, when installed in rural areas, end up generating jobs both direct and indirect, because it allows that the areas where the turbines are arranged also are used for the livestock.
From this, the sectorial system of wind energy, toward the productive and industrial development, has undergone transformations in the global electrical planning, through public policies of governments. Country-specific, this public policies take different paths depending on the energy model already established in each site (Dutra \& Szklo, 2008a; RATINEN \& LUND, 20I2).

In Table 3, were listed the public policies at the national level which are now given to wind energy in countries with high production of that energy.

What we note is that the only policy to wind energy, that was created in all countries punctuated in Table 3, it is the reduction of fees for the equipment financing of implementation of wind farms. The reduction of funding rates, for Dutra and Szklo (2008a, 2008b), is relevant in order to make investment more attractive, as well as reducing initial costs, since that the implementation of the wind farms is to be paid in long-term.

With the same functionality, the second type of policy to the wind energy more driven by the governments of the investigated countries is the public investments, loans and grants. To this, it is understood that this type of policy is the most important for the wind energy industry, for the same reasons already mentioned above about the reductions of financing rates; interfering, no doubt, in the pricing of wind energy, reducing it, according to Berry (2009).

Still, other two policies have been focused on studies and discussions: tax incentives and auctions. The tax incentives have been an elemental advantage to producers of wind energy, that were introduced in the energy systems of several countries, and that made a great boost from the recommendations outlined in the Kyoto Protocol (Garbe, Mello and Tomaselli, 20II). In Brazil, for example, tax incentives

\begin{tabular}{|c|c|c|c|c|c|c|}
\hline Country & $\begin{array}{c}\text { Public investments, } \\
\text { financings or loans }\end{array}$ & $\begin{array}{c}\text { Reduction of taxes } \\
\text { for financings }\end{array}$ & $\begin{array}{c}\text { Fiscal incentives } \\
\text { to generation }\end{array}$ & Auctions & Feed-in rate & Share System \\
\hline United States & & $\mathrm{X}$ & $\mathrm{X}$ & & & \\
\hline China & $\mathrm{X}$ & $\mathrm{X}$ & $\mathrm{X}$ & $\mathrm{X}$ & $\mathrm{X}$ & $\mathrm{X}$ \\
\hline Brazil & $\mathrm{X}$ & $\mathrm{X}$ & $\mathrm{X}$ & $\mathrm{X}$ & & \\
\hline Denmark & $\mathrm{X}$ & $\mathrm{X}$ & & $\mathrm{X}$ & $\mathrm{X}$ & \\
\hline Canada & $\mathrm{X}$ & $\mathrm{X}$ & & $\mathrm{X}$ & & \\
\hline Spain & $\mathrm{X}$ & $\mathrm{X}$ & & & $\mathrm{X}$ & \\
\hline Germany & $\mathrm{X}$ & $\mathrm{X}$ & & & $\mathrm{X}$ & \\
\hline India & $\mathrm{X}$ & $\mathrm{X}$ & $\mathrm{X}$ & & & \\
\hline
\end{tabular}

Table 3. Policies in national level for to generation of wind energy in some countries. Source: Elaborated from Lema and Ruby (2007), Meyer (2007), Dutra and Szklo (2008a), Berry (2009), Gwec (2010) and Ratinen and Lund (20I2).

ISSN: 07 I8-2724. (http://www.jotmi.org)

Journal of Technology Management \& Innovation @ Universidad Alberto Hurtado, Facultad de Economía y Negocios. 
are of deducting of fees and exemption from ICMS (tax of transactions relative to the movement of goods and services rendered) on the equipment, which has been characterized as a avoided fixed cost (Nascimento, Mendonça and Cunha, 2012; Ribeiro, Pierot and Corrêa, 2012).

On the other hand, the auctions have been, generally, seen as a dichotomous factor of advantage and disadvantage. It is advantageous because the producer has the security to sell all his energy for a reliable buyer (the government), in a 20 years concession, for a determined and equal value, throughout the lease time, and regardless of market swings. And it becomes a disadvantage, especially, because the auction be of the reverse type, in which the bid prices are decreasing, thus, the producer usually sells his energy below the cost price (Costa and Pierobon, 2008; Garbe, Mello and Tomaselli, 20II). Related to this, Lema and Ruby (2007) warn about this downside of auctions, because in recent auctions of wind energy that occurred in China, the falling prices, due to competitiveness of producers, presented a serious loss for the electricity producer companies.

In Brazil, according to dates from National Electric Energy Agency (Aneel, 2012), in 20II, in energy auctions, the sale price of wind energy electricity in Brazil reached $R \$ 99.54$ / MWh, a value $67 \%$ below the price in 2009 , which was around R\$ 148.39/MWh. With these features, Brazil has become one of the countries that sell wind energy with the cheapest price in the world, still according to the Aneel (2012); it is worth noting that this value is below the cost price of this electricity production.

These policies related to wind energy in Brazil emerged with the establishment of PROINFA (Incentive Program for Alternative Sources of Energy) in 2004, based on the triad: (I) stable rules, (2) safety and (3) low tariffs. Thus, the Brazilian electric power system started to emphasize in more universal issues, as well as, issues of the price and environmental stability. Consequently, the commercialization format of electricity has become dependent on the opening of electric power auctions, of tax incentives and of authorization of funding, to that wind energy projects become viable and so the price can becomes more competitive (Dutra and Szklo, 2008a; 2008b).

\section{Market opportunities to wind energy}

In consideration to the perspectives concerning to green marketing strategies and to opportunities of the wind energy industry, the marketing issues become more evident to verification. Related to this, Leite, Borges and Falcão (2006) argue that the companies which enter in the wind energy industry must make an assessment of the implementation of the wind farms to be built, in which, they must look at the issue of wind potential and to the issues which interfere in planning and operation of the electricity system. In this sense, "the operative characteristics of the wind plant, are heavily dependent of the local regime of winds, that makes the model of generation of a conventional power plant cannot be directly applied to it" (Leite, Borges and Falcão, 2006: 178).

\section{Brazilian potential of wind energy}

By the complementation of digital maps with geo-processing capabilities, performance and electricity production calculations of wind turbines, Amarante et al. (200I) point out estimated values of wind potential in Brazil that can assist in decision-making of investors of this sector, about which locations are most feasible to installation of wind energy. Furthermore, it is known that wind energy is "entirely reasonable in most of the Brazilian territory from the perspective of the existence of a vast wind potential for immediate and reliable use" (Silva, Rosa and Araújo, 2005: 289).

Figure I shows the Brazilian wind potential subdivided by regions. Brazil has a wind potential of $143.5 \mathrm{GW}$ - with 50 meters high turbines and winds with at least $7 \mathrm{~m} / \mathrm{s}-$, in which, the Brazilian northeast assumes $52.2 \%$ of this potential, with $75 \mathrm{GW}$. More specifically, this potential lies in the states of Rio Grande do Norte and Ceará which hold $84.48 \%$ of the wind potential of the northeast region (Aneel, 2008).

What already has revealed is quite promising. However, there is a new trend in wind energy generation in Brazil, which are the wind turbines to 100 meters high, which cap-

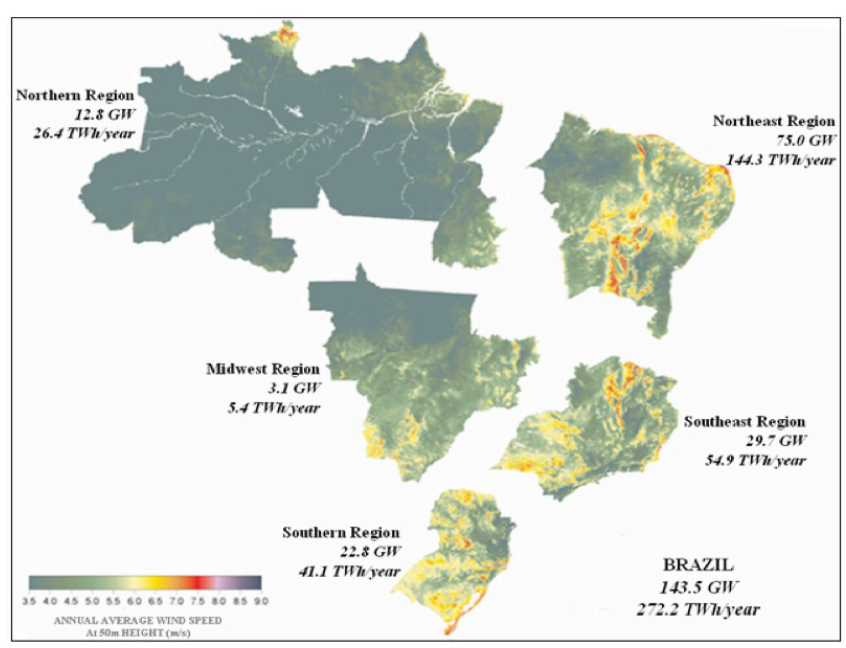

Figure I. Estimated wind energy potential for average annual wind higher than or equal to $7.0 \mathrm{~m} / \mathrm{s}$. Source: From Amarante et al. (200I: 44). 
ture winds average about $10 \mathrm{~m} / \mathrm{s}$ (Cni, 2009). Recent studies, based on these new turbines, indicate a wind potential in Brazil of $350 \mathrm{GW}$, that is about three times the energy demand of Brazil, which at the end of 2010 had a need to II3.4 GW (Gwec, 2010).

Berry (2009) explains that the expanding of generation capacity was accompanied by innovations in the development of wind turbines, and therefore, the current wind turbines are at a high level of energy production, which opens space in sector and opportunities of business for new ventures. Notwithstanding, the author warns that not always wind turbines of higher capacity of energy generation and most technologically advanced are good opportunities, because, in proportion that occurs the improvement of production, there may be risks of operating and maintenance problems, because according to the author "new designs may initially require development of new supply chains for customized components, possibly resulting in higher manufacturing costs" (Berry, 2009: 4494).

From this, it is worth noting that despite the difficulties, Leite, Borges and Falcão $(2006)$ claim that wind energy generation in Brazil is timely, because the wind potential is extremely favorable to exploration. Moreover, "the capacity factors calculated were between $30 \%$ and $40 \%$, value which is considered high by world standards" (Leite, Borges and Falcão, 2006: 187), putting Brazil in evidence in terms of wind energy production. Still for authors, preoccupation with the economic viability and wind potential is essential to the strategic planning of an energy producing company, because a wind farm can be attractive for a producer, considering the installation location, the wind potential, the capital of investment, the country's economy, the competitive market and the government subsidies, but may be not attractive to another producer, considering the same factors.

\section{Socio-environment issues and Green Marketing}

The socio-environmental issue of wind energy is another point widely discussed in the literature, in which, relate to the reduction of spending by the countries governments, because can be decreased about 56 Euros in fuel costs each year per MW of wind energy installed capacity, and reduce about 1.26 tons of $\mathrm{CO} 2$ in a year per $\mathrm{MW}$ in the same conditions (Delarue, Luickx and D'Haeseleer, 2009; Bryce, 20II).

Hence, the conduct of public policy to development of this sector has encouraged a socio-environmental, innovative and sustainable stance of the companies. Barbieri et al. (2010: 153) explain that the new "innovative and sustain- able standard of organization is a response to institutional pressures for an organization that is able to innovate with efficiency in economic terms, but with also social and environmental responsibility".

Still, as stated by Ribeiro, Pierot and Corrêa (2012), this type of position focused on environmental responsibility and sustainability becomes an indicator for good management of modern enterprises. To this, Dias (2009) points out that not only these incentives are attractive for electric power companies to production in scale, but also for the production of wind energy, as part of a process of environmental resource management and green marketing.

Despite the wind energy industry is getting several incentives due to sustainable energy policies and environmental protection, the studies show that there are some impacts related to the wind energy generation system. These impacts must be taken into account in the analysis to environmental viability of this energy source (Salles, 2004; Reis and Cunha, 2006). Salles (2004) e Reis and Cunha (2006) punctuate as impacts, such things as: Electromagnetic interference in TVs, radio, cell phones etc.; Interference in the winged fauna; Amendment of Landscapes; Amendment of usability soil; and, Risks of rupture of the towers structure components.

Meanwhile, other issues influence that such factors are treated irrelevantly in Brazil, as the domestic power market that is in a need to supplement the hydropower supply, since the crisis in the Brazilian electric sector in 200I. Thus, wind energy can become a solution to these problems (Silva, Rosa and Araújo, 2005; Araújo \& Freitas, 2006). Thus, retakes the conceptualization of green marketing and environmental resource management; because these concepts are bonded structurally to the establishment of renewable energy production, which is intrinsic to the business format of the wind energy. At point that policies, incentives, opportunities and viability coexists, at the same time, the environmental position of the company is to have a strategic idealism, and not just a set of fragmented techniques of commercialization of products or services, which do not harm the environment (Dias, 2009).

Dias (2009: 142) explains that green marketing "is a way of articulating the relationship between the consumer, the company and the environment", being a marketing philosophy with ecological aim that must be steeped in the everyday behavior of the organization. The need for this strategy plan is subject to a new type of consumer, who is concerned about environmental issues, in such forms that green marketing has become a phenomenon in the marketing scope. 
This behavior of consumer environmental awareness goes beyond the commercial and industrial sector, and becomes a new paradigm for public policies. From this, spending on R\&D (Research and Development) for the wind energy sector became an obligation imposed by both governments and consumers, to companies working in this sector, according to Alves et al. (201I). More than that, the companies that use green marketing will probably have a competitive advantage in the market (Dias, 2009). Opportunities for wind energy production on a scale is limited to a high monetary return within the long-term, and extend to the commercial environment, of self-production companies in various sectors, as part of an environmental resource management strategy (Dutra and Tolmasquim, 2002; Ribeiro, Pierot and Correa, 2012).

\section{Methodology}

The methodological basis of this study is configured within an exploratory approach; given the thematic study about the market perspectives of wind energy is still beginning on investigations and researches. Gil (2012: 27) justifies that the exploratory research should be developed "with the goal of providing general overview, of approximate type, about a specific fact", especially when the subject is still little explored and there is a need for operationalization of the basic information of the problem investigated.

Beginning this prerogative, the study adopted a qualitative analysis format, which according to Malhotra (201I), is oriented in a cyclical and concomitant process to data collection. In other words, at the point that begins the theoretical review about the marketing aspects of wind energy within the Brazilian electricity market starts simultaneously an inductive and interpretative analysis, in order to define future themes and actions of researches.

In this sense, was performed a SWOT analysis of the Brazilian wind energy sector, according to which Panagiotou (2003), claims to be a kind of analysis appropriate to the early stages of strategic planning and market analysis, and it is complementary to the studies of exploratory approach. As the wind energy market is composed, in its systemic structure, of internal and external variables, it is appropriate the evaluation of the internal capabilities (Strengths and Weakness) and external capacities (Opportunities and Threats) of the wind energy sector.

Still, Panagiotou (2003) warns that the SWOT analysis becomes unsuitable for unstable markets. To this, one takes as premise, indicate that these analysis merely make up the current electricity scenario of Brazil, which has remain stable since the creation of the Incentive Program for Alternative Sources of Energy - PROINFA - in 2004.
The SWOT as a tool of analysis in this study was adopted, on the premise that the companies to enter in new markets require a complete analysis of the sector that it is inserted, and should answer the core of competencies and internal weaknesses.

In this sense, the methodology proposed by Panagiotou (2003) that is from the SWOT analysis, The "Telescopic Observations Strategic Framework" shows better adapted to this study because through this method, was generated a SWOT matrix that encompasses several dimensions of analysis, in which, was taken as premise that the interference factors incite in a wind farm or a wind energy project. To the development the analysis "Telescopic Observations Strategic Framework" was used as basis the theoretical review of this study in a process of analysis and continuous reflection. Therewith, the results collected are complementary with the literature, at the point to this deepens in the study, starting of a theoretical format of analysis.

\section{Results}

\section{SWOT analysis in the Telescopic Observations Strategic Framework}

In order elementary, one comes to the mapping of the marketing factors of wind energy through of the chosen analysis model. In Tables 4 and 5 it can be found the SWOT analysis for the interference components in organizational strategy, through of the utilization of the analysis table of "Telescopic Observations Strategic Framework", proposed by Panagiotou (2003). "As its name suggests, the framework scans and observes distance objects, focuses and zooms in them, and brings them closer to the user for a more effective analysis and evaluation" (Panagiotou, 2003: 9).

Furthermore, the table of "Telescopic Observations Strategic Framework" also includes the analytical points of the competitive forces of Porter (1980): Buyers, Suppliers, Competitors, New Entrants and Substitute Products - as can be seen in Tables 4 and 5 .

The Tables 4 and 5 are divided the analytical points of Internal Environment (Strengths and Weakness) and External Environment (Opportunities and Threats). Some points are elementary and self-explanatory in their dimensions, as technological advances - highlighted as an opportunity in the wind energy sector -, in which made the equipment for the turbines more efficient and cheaper (Cni, 2009).

Other points, in turn, require a further analysis as the structure and culture of the organization and the total quality management, which are evidenced as the sectorial 
competitive forces. Ribeiro, Pierot and Corrêa (2012: 68) found that wind energy companies have a lean structure profile (average of 50 employees), and that these collaborators have "a involvement regarding the sustainability of average awareness", and besides having an organizational quality strategies as "programs of environmental education", monitoring and control of environmental issues, a system of risks management, among others; which justifies the choice of such competitive forces to the wind energy sector in the SWOT analysis.

Regarding to the Weaknesses, issues such as Portfolio, Electronic Commerce and Industry key factors for success, need a current explanation. Firstly, Portfolio of a wind energy company is simplistic, because covers only the production of a type of energy; Contiguous, the Electronic commerce presents many problems not only to the sale of energy but also to the sale of turbines, because they are products/services of high value and high structural, systemic and technological grade; And, the lack of Industry key factors for success are problems of a modern industry, that still depends on many environmental, economic and political variables for support within the electricity market (Costa, Casotti and Azevedo, 2009).
Regarding to the Opportunities, the International issues and the Value Chain, also need a current explanation. The International issues commonly are within of an environment of support and encouragement for wind energy generation, with investments in R\&D (Research and Development) and production of knowledge in this area, since the development of equipment technologically more advanced involves researches from several countries (Lewis and Wiser, 2007; Alves et al., 20II).

In turn, the Value Chain in the context of relationships with the stakeholders (Porter, 1980) tends to bring benefits for wind energy projects, since that both suppliers and buyers, as companies in the wind energy industry have given openness to creation of value through of strategic networks, configured as the opportunities in the sector.

Regarding to the Threats, precisely three of the competitive forces of Porter (1980) were characterized in this dimension: Suppliers, New entrants and Substitute products and services. First, in Brazil, only three companies operate in the supply of turbines and equipment for wind farms, demonstrating a threat to the expansion of the sector, as well as, to become this kind of power more widespread,

\begin{tabular}{|c|c|c|c|c|c|c|c|c|c|c|}
\hline & \begin{tabular}{|l|} 
T \\
Technological \\
Advancements
\end{tabular} & \begin{tabular}{|l} 
Economic \\
considerations
\end{tabular} & $\begin{array}{l}\text { Legal and } \\
\text { regulatory } \\
\text { requirements }\end{array}$ & \begin{tabular}{|l|} 
E \\
Ecological and \\
environmental \\
$\quad$ issues
\end{tabular} & $\begin{array}{l}\mathbf{S} \\
\text { Sociological } \\
\text { trends }\end{array}$ & $\begin{array}{l}\text { C } \\
\text { Competition }\end{array}$ & \begin{tabular}{|l|}
0 \\
$\begin{array}{c}\text { Organisational } \\
\text { culture }\end{array}$
\end{tabular} & $\begin{array}{l}\mathbf{P} \\
\text { Portfolio } \\
\text { analysis }\end{array}$ & \begin{tabular}{|l|} 
International \\
issues
\end{tabular} & $\begin{array}{l}\text { cost } \\
\text { efficiencies } \\
\text { and cost } \\
\text { structures }\end{array}$ \\
\hline Strengths & & $x$ & & & & & $x$ & & & \\
\hline Weaknesses & & & & & & $x$ & & $x$ & & $x$ \\
\hline Opportunities & $x$ & & $x$ & $x$ & $x$ & & & & $x$ & \\
\hline Threats & & & & & & & & & & \\
\hline
\end{tabular}

Table 4. SWOT analysis in "Telescopic Observations Strategic Framework" of the Brazilian wind energy sector. Standard table from Panagiotou (2003, p. 10).

\begin{tabular}{|c|c|c|c|c|c|c|c|c|c|c|c|c|}
\hline & $\begin{array}{l}0 \\
\text { Organisat. } \\
\text { ional core } \\
\text { com- } \\
\text { petencies } \\
\text { and } \\
\text { capabilities }\end{array}$ & Buyers & S Suppliers & $\begin{array}{l}\mathbf{E} \\
\text { Electronic } \\
\text { commerce }\end{array}$ & $\begin{array}{l}\text { Resource } \\
\text { audit }\end{array}$ & $\begin{array}{l}\text { V } \\
\text { Value chain }\end{array}$ & $\begin{array}{l}\text { A } \\
\text { Alliances } \\
\text { (including } \\
\text { partnerships. } \\
\text { networks \& } \\
\text { joint } \\
\text { ventures) }\end{array}$ & \begin{tabular}{|c|} 
T \\
Total \\
Quality \\
Manasement
\end{tabular} & $\begin{array}{l} \\
\text { Industry } \\
\text { Key } \\
\text { Factors for } \\
\text { Success }\end{array}$ & $\begin{array}{c}0 \\
\text { Organisa. } \\
\text { tional } \\
\text { structure }\end{array}$ & $\begin{array}{l}\text { New } \\
\text { entrants }\end{array}$ & $\begin{array}{l}\text { S } \\
\text { Substitute } \\
\text { products } \\
\text { and } \\
\text { services }\end{array}$ \\
\hline Strengths & & & & & $x$ & & & $x$ & & $x$ & & \\
\hline Weaknesses & $x$ & & & $x$ & & & & & $x$ & & & \\
\hline Opportunities & & $x$ & & & & $x$ & $x$ & & & & & \\
\hline Threats & & & $x$ & & & & & & & & $x$ & $x$ \\
\hline
\end{tabular}

Table 5. SWOT analysis in "Telescopic Observations Strategic Framework" of the Brazilian wind energy sector. Standard table from Panagiotou (2003: 10).

ISSN: 07 I8-2724. (http://www.jotmi.org)

Journal of Technology Management \& Innovation @ Universidad Alberto Hurtado, Facultad de Economía y Negocios. 
according to the Cni (2009). Moreover, the New Entrants enter in the market with the technology for wind energy on the rise, with several experiential cases of wind farms, to guide the decision-making and with a sectorial stability due to public policies established. On the other hand, the Substitute products, such as solar and biomass power which are also renewable -, have had a generation potential and growth as much as wind energy.

Thus, from SWOT analysis of type "Telescopic Observations Strategic Framework" for Brazilian wind energy industry, were highlighted more factors of the Opportunities, followed by the Weaknesses, as can be seen in Figure 2 the frequency of each dimension of SWOT analysis. Can be understood that of internal factors, a wind energy project tends to have more Weaknesses, in particular, for being a new variety of organization and that deals with innovation issues. In compensation, from external factors, a wind energy project tends to have more Opportunities, due to policies of encourage to clean energy generation and to the expressive wind potential of Brazil.

\section{Specific SWOT analysis}

In a specific SWOT analysis, in complement to the analysis of "Telescopic Observations Strategic Framework", was proposed to investigate what marketing factors more affect the wind energy industry, in the dimensions of Strengths, Weaknesses, Opportunities and Threats. As can be seen in Table 6, many factors interfere in the wind energy market; with some factors, analytically, more relevant in terms of organizational strategy than others.

In the dimension of Strengths, the strategy factor of Green marketing is characterized as the most relevant, especially because it is making the wind energy so attractive and predisposed to many incentives to production. Such strategic and ecological policies, as defined by Dias (2009), had begun when the companies found themselves compelled to adapt to environmental demands of new markets, which are seeking to reduce environmental contamination, as is the case of the sectors of renewable energy, including there the wind energy.

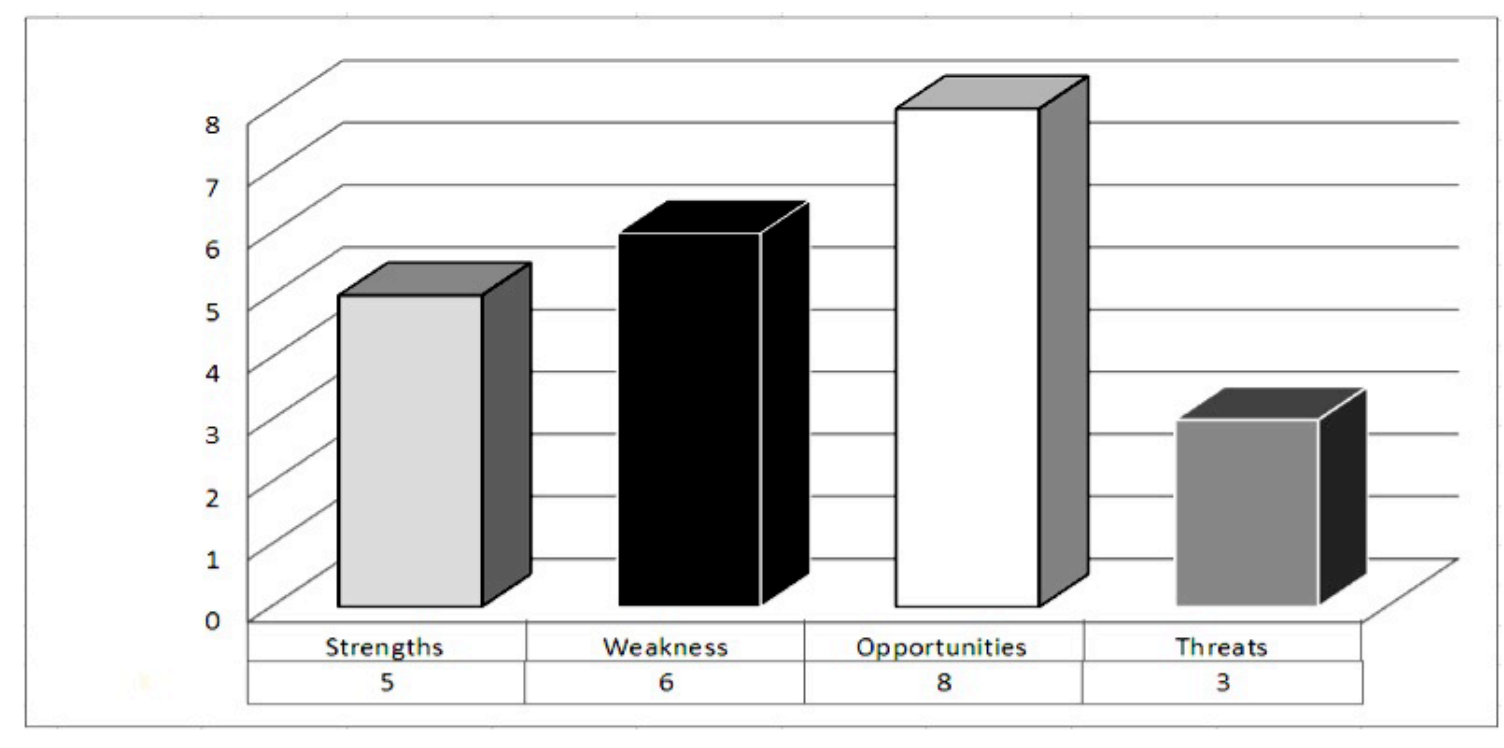

Fig. 2. Frequency of each variable of SWOT analysis. Prepared by the authors.

\begin{tabular}{|l|l|l|l|}
\hline \multicolumn{1}{|c|}{ STRENGTHS } & \multicolumn{1}{c|}{ WEAKNESS } & \multicolumn{1}{c|}{ OPPORTUNITIES } & \multicolumn{1}{c|}{ THREATS } \\
\hline Quality of energy; & Limitation to specific locations; & Wind energy potential; & Lack of transmission lines; \\
Green marketing; & High initial costs; & Reduction rate; & Solar and Biomass power; \\
$\begin{array}{l}\text { No costs of management, op- } \\
\text { eration and maintenance; }\end{array}$ & Auctions [commercial view]; & Financing and loans; & $\begin{array}{l}\text { Auctions [concession view } \\
\text { - competition]; }\end{array}$ \\
Organizational structure dry; & Lack of specialized workers; & Alliances and networks; & New high entrants; \\
\hline
\end{tabular}

Table 6. Specific SWOT analysis of the Brazilian wind energy sector. Prepared by the authors.

ISSN: 07 I8-2724. (http://www.jotmi.org)

Journal of Technology Management \& Innovation (c) Universidad Alberto Hurtado, Facultad de Economía y Negocios. 
In dimension of Weaknesses, the high initial costs of equipment are the determining factor for the implantation of a wind energy project. Notwithstanding, other issues that are intrinsic to the organizational environment of electric power generation companies, should also be carefully evaluated, such as the competitiveness capability, the limitations of the locations of the wind energy project installation and the lack of specialized employees with specific skills and capacities.

In dimension of Opportunities, despite of the big question for the wind sector that is the funding and subsidies, which enables the economic viability of wind energy project; on strategic terms are the networks and alliances the most relevant Opportunities factors. This is because, due to high implementation costs and the risks concerning the sector, the strategic partnerships become a way for companies overcome these problems, through the sharing of organizational capabilities and capital, in favor of the viability of wind energy projects.

A specific Brazilian case is of the companies Vale S.A. (Brazilian) and Pacific Hydro (Australian) which formed a joint venture to build in the state of Rio Grande do Norte that has the greatest wind energy potential of Brazil - wind farms with installed capacity of I40MW and an investment of R\$ 650 million (Pacific Hydro, 2012).

In dimension of the "Threats", there is the competitiveness of electric power auctions, which has led producing companies to commercialize the energy below of the cost price, due to an expectation of sale of wind energy produced. Costa, Casotti and Azevedo (2009) and Garbe, Mello and Tomaselli (20II) point out that in Brazil the prices of wind energy have been forced down because of the competition environment in the energy auctions, which make the wind energy projects, that are not economically viable at the price established, win the auctions and with it, present considerable loses, becoming a threat to these projects.

However, it is worth noting that a major threat to wind energy projects in Brazil, despite not been a strategic factor, is indeed the governmental structure and support, it is, the lack of power transmission lines that connect the wind farms to the power grid, in order to complement the hydroelectric regime (Silva, Rosa and Araújo, 2005; Dutra and Szklo, 2008a). Namely, at the point that wind farms are unable to sell the energy produced, this energy is wasted. Related to that, could be evidenced in Brazil that several wind farms that are stopped functioning, precisely because of the problem of transmission lines.

\section{Discussion}

The results found show a wind energy market with many opportunities and weaknesses, which, through the SWOT analysis "Telescopic Observations Strategic Framework" were the items in greater features. Featuring the Opportunities can be highlighted: Wind energy potential; Tax reduction; Financing and Grants; Networks and Alliances. As for weaknesses, can be highlighted: lack of transmission lines; solar and biomass power; auctions [concession view - competition]; new high entrants.

What was evident is that the Brazilian wind energy industry is eager to investments and has great potential to the creation of new businesses - wind farms and self-production -, due to the wind energy potential that the country has, coupled with a significant reduction of taxes for producers, as well as various incentives (grants, funding and support for environmental responsibility) that make up a functional system to overcome the barriers arising from investments by high initial cost, because impels reductions in effective costs or transform much of the initial costs to become costs of long term.

On the other hand, it is the problematic of endogenous character to the energy companies which should be assessed, such as: (I) the competitive power and auctions from competition perspective, because, the producer can hardly compete with large companies or with solar and biomass power which is cheaper than wind energy; (2) the high cost of equipment, which is a matter of technological learning, since the wind technology has an advanced and expensive system, and so, probably, only with the popularization of wind energy that costs will tend to fall significantly; (3) the limitations of the locations of installation because a variety of places of high wind potential (Figure I) are in the coast areas, requiring more active participation of government in encouraging and promoting wind energy, that can overcome in the process the lack of transmission lines that provide the a complement for the wind energy with hydropower - conventional in Brazil; and lastly (4) lack of skilled employees, which occurs due to not popularization of wind energy, so that there is a still low promotion of technical training in this area for the locals.

Still, one cannot fail to point out that other specific issues in Brazil about the political-economic model, the infrastructure and energetic industry influence the wind energy market, such as: (I) political-tax interests - since tax revenues for Government would be concentrated in the itself State Producer -, (2) knowledge and innovations that depend on other countries, (3) the public investment in the logistics of distribution networks, (4) the energetic risks related to continuity of energy supply versus political image 
of the possibility of a power outage (blackout), and (4) good regulatory mechanisms ensuring the power supply.

From this, is worth to point out that some marketing points have a universal reach, as strategic alliances, incentives for energy production, green marketing and organizational structure of companies of wind industry that should be equalized regardless of the country. Other points, such as lack of infrastructure for the implantation of wind farms or a supply very precarious of wind energy equipment, as well as their respective maintenance that can guarantee supply and distribution of energy are expressive of certain regions of the world, as Brazil.

\section{Concluding remarks}

In order to map the specific marketing factors of the Brazilian wind energy sector, due to managerial, strategic and commercial development of the sector, there was conducted a theoretical and empirical study, in which, were found relevant results to the design of future researches in the area.

From this, the SWOT analysis proved to be an excellent tool for broad issues, such as the energy systems. The subdivision of the dimensions on Strengths, Weaknesses, Opportunities and Threats also helped in mapping of the market factors, in order to create a pattern of results.

Furthermore, this study concretized its objectives and reaches its end point at the moment which demarcates the market factors influencing the wind energy sector, and thus, assesses the highlighted factors that can guide the managerial maturation of the sector and show the barriers and facilitators of wind energy businesses.

Also, the study of the market prospects of energetic sector is important for wind energy to become an alternative economically and managerially feasible for the industry, with support for environmental issues. This demonstrates that this study as a process of innovation management is necessary to complement the promotion policies that lead the planet to a technological innovation that reduces environmental impacts associated with economic interests.

Thus, it is understood that a deepening in the theme of wind energy related to marketing terms is of a great relevance to the wind energy industry in global scope, since there are almost none studies in this direction. And especially, related to the Brazilian electricity sector, this marketing research of wind energy reaches a particular level of innovation management, in order to become the starting point for any study in this regard.
The limitations of this research arise mainly because its exploratory format, which had an alignment in data collection and data analysis in search of qualitative variables for map the marketing factors of relevance for the Brazilian wind energy industry. Accordingly, further strict and specific studies are recommended to assess the market factors raised here, especially in quantitative approaches, for example investigations regarding costs, investments and innovations, in order to assess progress, since the prospect of use and implementation of this new energy source is large, but limited under marketing approaches that were highlighted here.

\section{References}

AGÊNCIA NACIONAL DE ENERGIA ELÉTRICA - ANEEL (2008). Atlas de energia elétrica do Brasil. (3th ed.). ANEEL, Brasília.

AGÊNCIA NACIONAL DE ENERGIA ELÉTRICA - ANEEL (2012). Processo $n^{\circ} 48500.00674$ I/20 II-5I: regulamentação do Art. 21 da Lei no 11.943 de 28 de maio de 2009. (p. I-7 from technical note $n^{\circ} 002 / 2012-S R G / A N E E L$, in 0I.13.2012). http://www.aneel.gov.br/aplicacoes/audiencia/ arquivo/2012/023/documento/nt_002-2012-srg-aneel.pdf [Accessed September 12, 2012]

ALVES, A. P., Silva, T. G., Macedo, M. A. S., Marques, J. A. V. C. (20II). A relevância dos gastos com P\&D para o mercado brasileiro de capitais: um estudo com distribuidoras de energia elétrica no período de 2002 a 2009. Revista de Administração e Inovação, 8(2), 216-239.

AMARANTE, O., Brower, M., Mack, J., Sá, A. L. (Org.). (200I). Atlas do potencial eólico brasileiro. CRESESB/ ELETROBRAS/CEPEL/MME, Brasília.

ARAÚJO, M., Freitas, M. (2006). Acceptance of renewable energy innovation in Brazil: case study of wind energy. Renewable and Sustainable Energy Reviews, 12(2), 584-59l.

BARBIERI, J. C., Vasconcelos, I. F. G. de, Andreassi, T., Vasconcelos, F. C.de. (20I0). Inovação e sustentabilidade: novos modelos e proposições. Revista de Administração de Empresas, 50(2), I46-I54.

BERRY, D. (2009). Innovation and the price of wind energy in the US. Energy Policy, 37, 4493-4499.

BHIDE, A. (2002). Como os empreendedores constroem estratégias que dão certo. In: Harvard Business Review, Empreendedorismo e estratégia (pp. 61-90). Elsevier, Rio de Janeiro. 
BRYCE, R. (20II). The high cost of wind energy as a carbon-dioxide reduction method. Manhattan Institute for Policy Research, II, I-9.

CONFEDERAÇÃO NACIONAL DA INDÚSTRIA - CNI (2009). Energia eólica: panorama mundial e perspectivas no Brasil. CNI, Brasília.

COSTA, R. C. da, Pierobon, E. C. (2008). Leilão de energia nova: análise da sistemática e dos resultados. BNDES Setorial, 27, 39-58.

COSTA, R. A., Casotti, B. P., Azevedo, R. L. S. (2009). Um panorama da indústria de bens de capital relacionados à energia eólica. BNDES Setorial, 29, 229-278.

DELARUE, E. D., Luickx, P. J., D'haeseleer, W. D. (2009). The actual effect of wind power on overall electricity generation costs and $\mathrm{CO} 2$ emissions. Energy Conversion and Management, 50, I450-1456.

DEVINE-WRIGTH, P., \& Howes, Y. (20I0). Disruption to place attachment and the protection of restorative environments: a wind energy case study. Journal of Environmental Psychology, 30(3), 27I-280.

DIAS, R. (2009). Gestão ambiental: responsabilidade social e sustentabilidade. Atlas, São Paulo.

DUTRA, R. M. (2007). Propostas de políticas específicas para energia eólica no Brasil após a primeira fase do PROINFA. Doctoral Thesis, Engineering Program, Universidade Federal do Rio de Janeiro, Rio de Janeiro, RJ, Brazil.

DUTRA, R. M., Szklo, A. S. (2008a). Incentive policies for promoting wind power production in Brazil: scenarios for the alternative energy sources incentive program (PROINFA) under the new Brazilian electric power sector regulation. Renewable Energy, 33, 65-76.

DUTRA, R. M., Szklo, A. S. (2008b). Assessing long-term incentive programs for implementing wind power in Brazil using GIS rule-based methods. Renewable Energy, 33, 2507-25I5.

DUTRA, R. M., Tolmasquim, M. T. (2002). Estudo de viabilidade econômica para projetos eólicos com base no novo contexto do setor elétrico. Revista Brasileira de Energia, 9, $135-158$.

GARBE, E. A., Mello, R. de, Tomaselli, I. (20II). Projeto conceitual e análise de viabilidade econômica de unidade de geração de energia elétrica eólica na Lagoa dos Patos - RS. Economia \& Energia, 83, 24-48.
GIL, A. C. (2012). Métodos e técnicas de pesquisa social. (6th ed.). Atlas, São Paulo.

GLOBAL WIND ENERGY COUNCIL - GWEC. (20I0). Global wind report: annual market update 2010. GWEC, Brussels.

GÖKÇEK, M., Genç, M. S. (2009). Evaluation of electricity generation and energy cost of wind energy conversion system (WECSs) in Central Turkey. Applied Energy, 86, 273I-2739.

KOMOR, P. (2004). Renewable energy policy. Diebold Institute for Public Policy Studies, New York.

LEITE, A. P., Borges, C. L. T., Falcão, D. M. (2006). Modelagem de usinas eólicas para estudos de confiabilidade. Revista Controle \& Automação, 17(2), I78-188.

LEMA, A., Ruby, K. (2007). Between fragmented authoritarianism and policy coordination: creating a Chinese market for wind energy. Energy Policy, 35, 3879-3890.

LEWIS, G. M. (20I0). Estimating the value of wind energy using electricity locational marginal price. Energy Policy, 38, 322I-323I.

LEWIS, J., Wiser, R. (2007). Fostering a renewable energy technology industry: an international comparison of wind industry policy support mechanisms. Energy Policy, 35(3), |844-|857.

MALHOTRA, N. K. (20II). Pesquisa de marketing: foco na decisão. (3rd ed.). Pearson Prentice Hall, São Paulo.

MEYER, N. (2007). Learning from wind energy policy in the EU: lessons from Denmark, Sweden and Spain. European Environment, 17(5), 347-362.

MILLS, A., Wiser, R., Porter, K. (20I2). The cost of transmission for wind energy in the United States: a review of transmission planning studies. Renewable and Sustainable Energy Reviews, 16, I-19.

NASCIMENTO, T. C., Mendonça, A. T. B. de, Cunha, S. K.da. (20I2). Inovação e sustentabilidade na produção de energia: o caso do sistema setorial de energia eólica no Brasil. Cadernos EBAPE.BR, I0(3), 630-65I.

PACIFIC HYDRO (2012). Vale e Pacific Hydro formam joint venture em energia eólica. (Company Pacific Hydro Energia do Brasil Ltda.). http://pacifichydro.com.br/2012/06/22/ vale-e-pacific-hydro-formam-joint-venture-em-energiaeolica/?language $=$ pt $[$ Accessed December 22, 2012] 
PANAGIOTOU, G. (2003). Bringing SWOT into focus. Business Strategy Review, 14(2), 8-10.

PORTER, M. E. (1980). Competitive strategy. Free Press, New York.

RATINEN, M., Lund, P. (20I2). Analyzing changes in electricity industries against actors and technologies: utility to business transformations in Denmark, Germany, Finland and Spain. Journal of Technology Management \& Innovation, 7(2), 87-10I.

REIS, L. B. dos, Cunha, E. C. N. da. (2006). Energia elétrica e sustentabilidade: aspectos tecnológicos, socioambientais e legais. Manole, Barueri.

RIBEIRO, H. C. M., Pierot, R. M., Corrêa, R. (20I2). Projeto de mecanismo de desenvolvimento limpo: um estudo de caso na empresa de energia eólica do estado do Piauí. Revista de Administração, Contabilidade e Sustentabilidade, 2(2), Rio+20 Special ed., 61-75.

SALLES, A. C. N. (2004). Metodologias de análise de risco para avaliação financeira de projetos de geração eólica. Master dissertation, Program of Engineering, Universidade Federal do Rio de Janeiro, Rio de Janeiro, RJ, Brazil.

SILVA, N. F. da, Rosa, L. P., Araújo, M. R. (2005). The utilization of wind energy in the Brazilian electric sector's expansion. Renewable \& Sustainable Energy Reviews, 9(3), 289-309.

YANG, W., Tavner, P. J., Crabtree, C. J., Feng, Y., Qiu, Y. (20I2).Wind turbine condition monitoring: technical and commercial challenges. Wind Energy, 15(8), Special issue paper. 